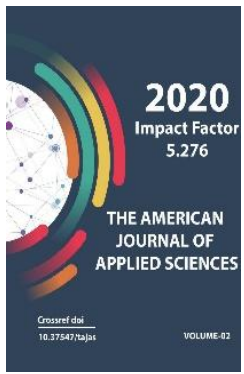

\title{
Dialectal Words In Sorbon's "Valley Of Snakes" (Dashti Moron)
}

Husniddin Normurodov

Researcher, Samarkand State University, Samarkand, Uzbekistan

Journal Website:

http://usajournalshub.c

om/index,php/tajas

Copyright: Original content from this work may be used under the terms of the creative commons attributes 4.0 licence.

\section{ABSTRACT}

The Sorbonne's "Valley of Snakes" (Dashti Moron) has a place in modern Tajik literature and differs from other works of the author in terms of language and style. This article examines the dialectal vocabulary of the Sorbonne in the story "Valley of Snakes" (Dashti Moron), their importance in the play, their use in ordinary people, in their speech and in informal conversations in the process of expressing negative and positive thoughts and opinions.

\section{KEYWORDS}

Dialect, vocabulary, Sorbon, language and style, lexeme, layer, speech process, Tajik literature.

\section{INTRODUCTION}

An important part of the lexical layer of any language consists of words belonging to certain dialects. Dialectal-specific lexemes and phrases are mainly formed in the vernacular and used in an oral (verbal) style in a logical sequence. Usually these types of words are not used in the language of formal relations and scientific works. Dialect words are mainly used in ordinary people's behavior, in the process of their speech and in informal 
conversations in the process of expressing mutual negative and positive thoughts and opinions and goals.

The content and theme of the famous Tajik writer Sorbon's story "Valley of Snakes", its reality, image, course of events, the need for artistic interpretation, to perfectly clarify the main ideas and goals of the writer, as well as to ensure the harmony of time and space in the work, had to resort more to his words.

\section{LITERATURE REVIEW}

The most important source in the author's work is the richness of dialect and dialect in the vernacular. In fact, every skilled artist manages to elevate to the level of an artistic emblem and a perfect image by sculpting this inconspicuous and ignorant object of the oral language at a simple level in the field of his creative process and criterion of thinking. The writer's ability to describe and create an image is determined by this criterion, otherwise the magic lines and miracles of the writer's pen lose their beauty and freshness, and the vocabulary and lexemes included in the work do not differ from ordinary words, affect the reader's artistic speech and mind.

In the language of fiction, dialectal words and phrases are used for a variety of purposes. The most important of them are:

1. The system of dictionaries used for the development of literary language:

In this case, dialectal words are used synonymously with words used in literary language, and sometimes some of these words strengthen their status in literary language due to the works of some writers.

Including: taffot (hot, hot wind): the hot wind of autumn, stalk-stalks: the ankles swept the ground stalk-stalk, niqqiy: no one niqqiy, burma: chin, ojing, dachkol: dachkol yol (dajgol), tognok: ( tognok place) rocky land and rare crops, patti-satti: while selling all patti and satti, and so on.

1. Methodological imitation or social stylization itself. In this section, dialectal words are used in the speech of the protagonists to determine their level of culture, level of knowledge, and profession and career. S.Ayniy used some words of this type together with their literary variants so as not to arouse suspicion in the readers.

2. That is, dialectal words gave literary variants of words on the basis of a dash (-) hyphen or parentheses. In particular, we can see this in the example of the words of the author's works qoq (golung), nimras (koktosh), vartish (bedona), bigiz (daravsh), charogak (lightning), omoch (sokhtuk). In some cases, S. Ayniy used the literary and dialectal forms of these words separately.

In this work, the Sorbon used purely artistic words instead of words that appeared randomly in the literary language.

\section{ANALYSIS}

This is also the case in the works of other writers, but the Sorbonne's method of creation differs from them in that the writer deliberately used these words more deliberately than others. Example: darafsh, polon, fuk, padar-andar, perception, suk, parvorid and others.

In the story of the Sorbon "Valley of Snakes" you can find a number of ancient languages and dialects. Some of them are in the dialect of ordinary peoples living in the Zarafshan valley and mountainous areas. But while some of these words are extremely rare in literary language, many are completely obsolete.

In particular, "xolondan", "marza", "lays" and others are known in the dialect and are not 
found in the literary language, or in many dictionaries and dictionaries.

Many of the dialectal words used in this story by the author are botanical, biological, and ethnographic terms and terms specific to the natural sciences. These types of terms used in the Sorbon story differ from their literary variants in content. These include: "parmuch" (wilting of the fruit of the tree), "daqqiy" (curling of the hair), "lux" (light-creating furnace), "kashu faxash" (war and quarrel), "farxosh" - "parhosh" (dictionaries war and quarrel), in the sense of "sarbez" (carefully sorting everything out), "kafa" (crushed wheat), "musak" (uncle and disrespectful), "xartush" (a large mulberry in a rock form), "munda" ( something short and concise, etymologically related to the word "mundi"), "xomxoba" (half-asleep, half-asleep), "murgak ketish" (symbolically juvonmarg to be a vegetable, spring and grass), "gur" (varam shish) and other words.

While in some cases the Sorbon used dialect words in a proper and proportionate manner based on the principles of logical sequence instead of some literary words, in some cases it overused dialect words and complicated the language of his works.

The Sorbon, like other great writers, made a significant contribution to the development of the Tajik literary language. In addition to the use of common words in dialect and oral speech, he managed to use and reconstruct historical and old words and phrases that were completely alien to the popular literary language, obsolete, and even unknown and incomprehensible to scientists [4].

As a result, some parts of these words and phrases gained their original literary status through the works of the writer. For example, "uva", "galmagal” (pp. 4, 9), "soniy" (pp. 4, 40), “guppiy” (pp. 4, 181), “jigot” (pp. 4, 181), "sabil qolish" (Pp. 4, 179), "tak zadan- yashirish" (pp. 4, 181), "garrora” (pp. 4, 125), "hang" (pp. 4, 16), and others.

A person who dies from accidental and extreme joy is called "shodimarg shud" (death from joy) in the vernacular. However, in the dialect of the peoples of Samarkand region and some districts, there is a phrase "shodikaf shudan" (burst of joy). The Sorbon used the same phrase in this context: "Az xursandi qarib ast, ki shodikaf shavand" (They were almost happy with joy) (4, p. 171).

Example: Sanginoy medonist, ki ba o' ob dodan lozim, ki misli guppy varam karda murad ... hamin lahza paydo shud in niyat ba'de ki shirin budani chonro az tapidanu gel gashtanhoi Vahshi did donist ... (Sanginoy knew that he should be given water he had to swell up like a guppie ... at that moment this intention was born - he knew that the soul was sweet only after seeing the suffering and wrapping of the Beast (p. 4, 181).

\section{DISCUSSION}

Concepts and terms that express kinship aspects in Tajik dialects differ not only lexically but also phonetically from their variants in other dialects. In particular, in some dialects the words "aka", "uka" and "bibi" (mothergrandmother) are pronounced in the forms "ako", "uko" and "buva" (mother). On the other hand, there are differences in the use of personal and possessive suffixes: "ukom" (brother), "akom" (brother) and "grandfather" (mother) (in Kanibadam and Isfara dialects), "ukem" (brother), "Akem" (brother) and "bibem" or "biyem" (mother) (in Samarkand and Bukhara dialects).

At the same time, it turned out that in the story "Valley of Snakes" the words "ocha" (mother), "ako" (aka) and "dodo" (dada) were used in the same style: - Zukur didn't understand that it was not enough to speak, as if it was enough to speak. 
In addition to the phrase "dil kafidan" (heart rupture) in this sentence, the phrases "shah shudan" (hardening), "gurda kafidan" and "gurdakaf shudan" (kidney rupture) are also known in different dialects. The phrase is given elsewhere as follows: "Qarib talhaam kafida bud" (Almost the passage was cracked) (p. 4, 20). "Ochajon, dilam dard mekunad" (Mother, my heart aches) (p. 4, 18). "Dodot boy boshad, charo zudtar zan nadod" (If your father is rich, why didn't he get a wife before?) (Pp. 4, 65).

In this story, the Sorbon also used repetitive words from his dialect: "fiq-fiq", "gir-gir", "milt-milt", "tik-tik", "ham-ham" and others. "Zukur qomat rost nakarda, sar ba sahfi kamarak merasidagi barin ham-ham pesh omad" (Zukur figure did not stand up, but his head rested on the belt) (p. 4, 19). "Hoh! angez dod sagonro, ammo onho dumak mezadandu yak qadam pesh monda, ba irinjirinj meguzashtand "(He pushed the dogs forward, but they moved their tails a step forward and moved to" irinj-irinj ") (p.19)

“ - Ho-ho-ho-ho! Gir-o gir! Ba ramai kamu xufta ro' ovarda sagonro hushyor mekard, to dar g'aflat namonand. - xoby, bacha?" (Ho-hoho-ho! Olu ol! He would turn to the low and sleepy rama and call the dogs to vigilance so that they would not be ignorant) (pp. 4, 23).

“ - Tag-tag... Dur-dur! - chonibi chanub dast burda, hamin xel surat mekard, ki o' niz zaboni go'yo nadoshta boshad" (Tag-tag ... Stop! - He stretched out his hand to the south, pretending that my uncle did not speak precise) (p. 4, 62).

“ - Tu gumon mekuni, ki sho'yatro man kushtam? Kushoyam, bubin, ki xel xirs saru ro'yo dastoni o'ro ajgo-ajgo kardaast"(Do you think that I killed your husband, When I opened it, I saw how the bear tore his face and hands) (4, p. 168).
“Chashmoni Sanginoy so'i modarsho' milt-milt kardand"(Sanginoy's eyes blinked at his mother-in-law) (pp. 4, 9).

From the above statements and in one of their repetitions, the word "ham" is repeated in the phrase "ham-ham pesh omad" (ham-ham came before). In another sentence, the repeated word "ajgo-ajgo" is used to mean biting and war. In the dialect of the Samarkand people, this meaning is known in the form of the repeated word "ajda-ajda" or the phrase "gajiy kardan" (to grind and grind). However, in many dialects these options are not observed. The repetitive words "irinj-irinj", "ajgo-ajgo", "fiq-fiq", "ham-ham", "tag-tag" and other similar words in this story belong to the dialect of the author's native peoples, and the writer uses them for a specific methodological purpose. used in his story.

In the works of the Sorbon, dialectal words, structures and expressions have a special artistic significance in ensuring the diversity and subtlety of the language of the work. On the other hand, the use of dialects in the age of the writer is not an accident, but a gradual process aimed at further enhancing the popular character of the writer's age, improving the principles of reality in the work.

“ - Chi, ika fiq-fiq mekuni? Ba gapi man xudo darav turo arusak soxtu man turo... astag'firulloh..." (Why are you so fiq-fiq? When I said that, God made you a bride in an instant and I ... astagfirullah ..." ) (pp. 4, 66). In this sentence, the pronoun "in qadar" (so much) is abbreviated in the character's speech in the form "iqa".

"... har goh az g'almag'ali sagon shubha karda az Sanginoy mepursid, ki in chi gap ast?" (... sometimes, suspicious of the noise of the dogs, he would ask Sanginoy, "What is he talking about?") (pp. 4, 9).

In this sentence, the word "g'almag'al" is used to mean the howls of dogs and their voices, and the author expresses this meaning in a 
dialect specific to his dialect. In the dialect of the Samarkand people, the word "tug'yon" is also used, meaning "riot", "rage" and "rebellion". However, in the Tajik Dictionary, the word means "sleep and rest".

\section{CONCLUSION}

This work is perfect in terms of language and style. The value of the work is further enhanced by the presence in it of historical words that are not found in the works of other artists, which are popular in the vernacular, and which are used in a certain range and are not found in other dialects and dialects. In the Sorbon's Valley of the Snakes, he sometimes used dialectal words instead of some disproportionate words of literary language in accordance with his ideological and methodological purpose, and in some cases he used dialectal words in excess of the norm, leading the story language to some extent out of literary language. One of the reasons for this is that the author has taken into account the fact that some dialects have reached the level of artistic status and the scope of consumption has expanded, while the level of consumption of some of them is still limited and narrow.

\section{REFERENCES}

1. Mahmudov M., Juraev G'. Tajik Shevahoi Dictionary. -Dushanbe, 1997.

2. G'afforov R. Writing and language. Dushanbe, 1997.

3. Grammar of modern Tajik literary language. Volume 1. Phonetics and morphology. -Dushanbe, 1985.

4. Sorbon. Dashti moron. Qissa. -Dushanbe, 1990.

5. Eshniyozov M. Tajik dialectology. Part 1. Dushanbe, 1977.

6. Eshniyozov M. Tajik Lahjashinosii. Dushanbe, 1996.

7. Homidov D. Tajik Shevashinosii. Dushanbe, 2016.
8. Sayfullayeva R., Mengliyev B., Bakiyeva G., Kurbanova M., Yunusova Z., Abuzalova M. Modern Uzbek literary language. -Tashkent: Science and technology, 2009. -415 p.

9. Annotated dictionary of the Uzbek language. I-V. -T .: National Encyclopedia of Uzbekistan, 2006-2008. T. I. 2006. -680 p .; T. II. 2006. -672 p .; T. III. 2007. -688 p ; T. IV. 2008. -608 p .; T. V. 2008. -592 p.

10. Mahmudov N., Khudoyberganova D. Annotated dictionary of Uzbek language analogies. -Tashkent: Manaviyat, 2013. $320 \mathrm{p}$. 